\title{
УГРОЗЫ НАЦИОНАЛЬНОЙ БЕЗОПАСНОСТИ В ЭПОХУ ЦИФРОВОЙ ТРАНСФОРМАЦИИ
}

\section{THREATS TO NATIONAL SECURITY IN THE ERA OF DIGITAL TRANSFORMATION}

\section{A. Voronov}

Summary. Based on the analysis of the chronology of the formation and development of legal regulation of digital transformation in modern Russia, in addition to the positive aspects accompanied by the introduction of new digital technologies, the author draws attention to a number of threats to psychological and moral security, which at the present stage of the development of Russian statehood act as a core ensuring the national security of the state.

These aspects of national security have received little or no attention, or are dealt with in a fragmented manner, in the context of the study of cross-sectoral issues. According to the author, psychological security, moral security are spiritual principles that determine the basic values of Russian statehood and are predetermining in modern Russia.

Keywords: digital technologies, digital transformation, national security, psychological security, moral security, security threats.

\author{
Воронов Алексей Михайлович \\ Д.ю.н., npopeccop, г.н.С., ФГКУ «ВНИИ МВД России» \\ alex_voronoff@mail.ru
}

Аннотация. На основе анализа хронологии становления и развития правового регулирования цифровой трансформации в современной России, помимо позитивных моментов сопровождающихся внедрением новых цифровых технологий, автор обращает внимание на ряд угроз психологической и моральной безопасности, которые на современном этапе развития Российской государственности выступают в качестве стержня, обеспечивающего национальную безопасность государства.

Данным аспектам национальной безопасности практически не уделяется внимания, либо они рассматриваются фрагментарно, в контексте изучения межотраслевых проблем. По мнению автора психологическая безопасность, моральная безопасность составляют духовные начала, определяющие базовые ценности российской государственности и являются предопределяющими в современной России.

Ключевые слова: цифровые технологии, цифровая трансформация, национальная безопасность, психологическая безопасность, моральная безопасность, угрозы безопасности.
Э волюция научной мысли необратима и имеет поступательное, прогрессивное изменение. Действительно, 21 век - век информационных технологий. Цифровая трансформация набирает обороты и проблемы, национальной безопасности связанные с ней, начинают затрагивать уже и межнациональные интересы. Цифровая трансформация коснулась всех сфер жизнедеятельности общества и интенсивно развивается, в том числе и в управленческой деятельности публичной администрации. В современной России появилось новое направление развития научной мысли цифровая трансформация.

Обращаясь к хронологии становления и развития данного феномена следует отметить, что в основе лежит Указ Президента Российской Федерации от 21 июля 2020 г. № 474 «О национальных целях развития Российской Федерации на период до 2030 года» [2], к числу которых отнесены: сбережение народа и повышение качества жизни граждан; обеспечение защищенности населения от внутренних угроз и вызовов во всех сферах жизнедеятельности; цифровая трансформация всех сфер жизнедеятельности и проч.

В целях реализации положений данного Указа принято Постановление Правительства Российской Федерации от 20 октября 2020 г. № 1646 «О мерах по обеспечению эффективности мероприятий по использованию информационно коммуникационных технологий в деятельности федеральных органов исполнительной власти» [3]. В документе отмечается, что в рамках цифровой трансформации должны происходить изменения государственных функций, таких функций как предоставление государственных услуг гражданам. Данные услуги должны предоставляться в цифровой форме.

Внедрение цифровых технологий будет оказывать существенное влияние на эффективность работы публичной администрации, способствовать совершенствованию взаимодействия государственных органов, общественных организаций, институтов гражданского общества в решении задач и функций государства 
по защите прав и свобод гражданина, обеспечение социально экономического развития государства, а также безопасности и обороны страны. Посредством цифровой трансформации должны коренным образом измениться качество деятельности органов публичной власти, в том числе и в сфере обеспечения национальной безопасности.

Утвердить стратегии цифровой трансформации отраслей экономики, социальной сферы и государственного управления Правительству поручил Президент по итогам заседания Совета по стратегическому развитию и национальным проектам[4] состоявшемся 5 августа 2021 г.

В развитие данных положений распоряжением Правительства Российской Федерации от 22 октября 2021 г. № 2998-р утверждено «Стратегическое направление в области цифровой трансформации государственного управления» [5], а 8 ноября 2021 г. Правительство РФ утвердило стратегическое направление в области цифровой трансформации социальной сферы[6] - единую цифровую платформу, объединенную в рамках искусственного интеллекта на базе больших баз данных для оказания публичных услуг гражданам в электронном формате, при этом предусмотренные в ее рамках проекты позволят сделать процесс получения мер господдержки максимально быстрым и удобным.

Данная платформа интегрировала в себе несколько важнейших в социально-экономической проектов, в рамках которых планируется обеспечить возможность простого и быстрого оказания публичных услуг гражданам и обеспечение мер социальной поддержки без предоставления справок и бумажных документов.

Обращаясь к заявленной проблематике уместно отметить, что выступая на международной конференции по искусственному интеллекту 12 ноября 2021 г., глава государства отметил, что следует подходить к внедрению технологий в первую очередь, заботясь о безопасности данных россиян. Представить, чтобы искусственный интеллект (ИИ) научился сопереживать и имел душу, трудно. Но вот то, что вы делаете, конечно, может быть предтечей ${ }^{1}$ того, в чем сегодня еще многие сомневаются. Важно чтобы такое начинание работало на благо человека, а не во вред[7[.

В мировом социуме как в Российской Федерации существует огромное количество угроз и вызовов безопасности, в связи с чем государственные администра-

\footnotetext{
Предтеча (др.рус.- течь, идти) - предшественник, лицо или событие, подготовившие условия для деятельности других, для проявления чего-то нового
}

ции, органы публичной власти, институты гражданского общества должны действовать в сфере обеспечения безопасности в тесном взаимодействии, как партнёры.

Помимо позитивных моментов сопровождающихся внедрением новых цифровых технологий, цифровой трансформации всех направлений обеспечений жизнедеятельности, следует обратить внимание на ряд угроз национальной безопасности, которые прежде всего состоят в том, что носители информации базовых систем разработаны и стоят на платформах зарубежных технологий. В связи с этим нашим «зарубежным партнерам», разработчикам данных технологий не представляется труда использовать их возможности в своих целях, достаточно лишь отключить систему питания, либо с помощью хакеров, взломав программное обеспечение, внести изменения в программы, тем самым дезорганизовать деятельность органов безопасности. Для ликвидации данных угроз представляется целесообразным разработка на основе информационных технологий отечественных системных платформ учета, накопления и анализа информации, в том числе больших банков данных. Об этом непосредственно прописано в Указе Президента Российской Федерации от 21 июля 2020 г. № 474, где одной из основных национальных целей развития Российской на период до 2030 года, как нами отмечалось ранее, является безопасная среда для жизни, предусматривающая обеспечение защищенности населения от внутренних угроз и вызовов во всех сферах жизнедеятельности, а также цифровая трансформация, в рамках которой увеличение вложений материальных средств в разработку именно отечественных решений в сфере информационных технологий в четыре раза по сравнению с показателем 2019 года и проч.

Ещё совсем недавно целью любого противостояния было нанесения экономических ущерба противнику, в настоящее время эти противостояния имеют гибридный, многоплановый характер и безусловно угрозы национальной безопасности в современных реалиях возникают в сфере научного и интеллектуального противостояния, в том числе и в сфере информационных технологий.

При рассмотрении вопросов безопасности выделяют проблемы национальной, государственной и общественной безопасности, представленные многообразием правовых институтов, составляющих их содержание. Абстрагируясь от их констатации представляется целесообразным обратить внимание на те из них, которые актуализировались именно в современной России.

В настоящее время, с учетом складывающейся напряженной геополитической обстановкой в мировом социуме, повышенным состоянием социальной напря- 
женности в России, вызванным, в том числе, продолжающейся третий год пандемией коронавируса, трансформируется методология обеспечения национальной безопасности. Основными направлениями деятельности публичной власти в области безопасности являются изучение и анализ тенденций угроз и оценка рисков.

При этом есть такие виды безопасности, которые практически не входят в структуру национальной безопасности. Особое место среди них занимает психологическая и моральная (духовно-нравственная) безопасность.

С позиции теории безопасности психологическая безопасность личности представляет собой состояние защищенности личности, обеспечивающее ее целостность как активного социального субъекта и возможности всестороннего развития в условиях информационных коммуникаций с окружающей средой.

Моральная безопасность представляет собой состояние защищенности жизненно важных духовно-нравственных интересов и потребностей личности, общества и государства, возникающих в процессе восприятия мира в целом, личного и общественного бытия.

Мораль существует всегда, в любом обществе, поскольку помогает людям комфортно существовать рядом друг с другом и адекватно оценивать реалии бытия 1.

Представляется, на современном этапе развития Российской государственности именно они выступают в качестве стержня, обеспечивающего национальную безопасность государства. Однако, как показал анализ достаточно большого массива источников, данным аспектам национальной безопасности практически не уделяется внимания, либо они рассматриваются фрагментарно, в контексте изучения межотраслевых проблем. По мнению автора психологическая и моральная безопасность составляют духовные начала, определяющие базовые ценности российской государственности и являются предопределяющими в современной России.

Военные теоретики прошлого говорили, что в противостоянии будущего линия фронта будет проходить не между государствами, а внутри каждой конкретной страны, конкретно в головах гражданского населения.

\footnotetext{
Мораль (лат. moralitas, термин введён Цицероном от лат. Mores «общепринятые традиции») Мораль-принятые в обществе нравственные нормы поведения, отношений с людьми. В некоторых языках, например, в русском, помимо слова мораль употребляется слово нравственность (в немецком - Moralität и Sittlichkeit), эти два слова чаще выступают в роли синонимов. https://ru.wikipedia.org/wiki/Мораль
}

Сегодня это будущее наступило. Идет гибридная война, которая подразумевает поражение населения так называемым «когнитивным оружием», под которым понимается внедрение в интеллектуальную среду страны противника ложных научных теорий, парадигм, концепций, стратегий, влияющих на ее государственное управление в сторону ослабления оборонно-значимых национальных потенциалов» [8, с.77-86].

При этом когнитивное оружие выступает детонатором для нового оружия противостояния - консциентального. Консциентальная угроза национальной безопасности представляется собой технологию работы с сознанием (по лат.- conscientia), которая нацелена на поражение и уничтожение определенных форм и структур сознания, а также некоторых режимов его функционирования. Это технология работы с сознанием, когда фронт проходит по головам людей.

Общеизвестно, что Запад ведет против России перманентно продолжающеюся информационную войну с целью ослабить ее позиции, как ведущей мировой державы. Интенсификация агрессивного информационного воздействия Запада связана с тем, что страна фактически вернула себе статус утраченного после распада СССР второго полюса, удерживающего мир в глобальном равновесии.

Невоенное противостояние, а точнее «холодная война» с Западом после распада СССР не прекращается ни на минуту. Это экспансия в части языка, веры, образования, культуры, морали, истории и прочих духовных и нравственных ценностей, и от адекватных оценок сегодняшних угроз в этой сфере зависит суверенитет и национальная безопасность России.

Развитие информационных технологий в современном социуме послужило дальнейшему становлению цифровой трансформации всех сфер жизнедеятельности. Помимо позитивных начал, направленных на благо человечества, данные факторы используются представителями Западных спецслужб в интересах гибридной войны в отношении Российской Федерации. С помощью новых цифровых технологий, в частности Big Data - объемы больших данных, можно манипулировать массовым сознанием населения и вплотную подходить к совершенствованию инструментов искусственного интеллекта.

Совершенно очевидно, что глобальной проблемой сегодняшнего мира является то, что США фактически не справились с ролью мирового лидера, позорно бежав из Афганистана, где более 20 лет они навязывали свои "демократические» устои. Ставя Россию в качестве своего политического оппонента США не лукавят, 
т.к. современная Россия действительно могучая ядерная держава, обладающая суперсовременным оружием и являющаяся главной сдерживающей силой противостояния амбициям США.

В таком противостоянии, в целях обеспечения национальной безопасности и территориальной целостности Российской Федерации нужно быть готовым длительному коммуникационному противостоянию, в том числе по защите собственных Big Data. При этом следует уделить особое внимание обеспечению психологической и духовно-нравственной безопасности гражданского общества.

Говоря о возможности развития турбулентности в гражданском обществе, следует отметить, что уровень самореализации протестного сообщества в России будет расти по вышеизложенным причинам, будет координироваться и финансироваться извне. Соответствующие НКО стремятся преумножить точки социального кипения на карте России. «Пятая колонна» и возглавляемые ими протестные группы будут всячески демонстрировать и провоцировать открытые конфликты с органами власти, с другими социальными группами гражданского общества.

Маргинальность этих активных групп, которые представляют несомненную опасность, очевидна и одновременно крайне привлекательна для социально незащищенных слоев населения. Через социальные сети и средства массовой информации ведется формирование образа якобы слабой власти. Бурно развивается движение «антипрививочников». Митинги против введения QR-кодов и обязательной вакцинации прошли уже во многих городах России. Люди обращаются к Президенту с просьбой остановить якобы сегрегацию и призывают власти к соблюдению конституционных прав граждан, до конца не понимая, либо не желая понимать под воздействием психологической подготовки наших оппонентов, что победить пандемию можно только всем миром и только путем вакцинации направленной на достижение публичного иммунитета.

Проведение гибридной войны силами протестных групп в гражданском обществе мы сейчас наблюдаем и на Украине, и в Грузии, и в Молдавии. Совмещение интересов молодежи и пенсионеров, хлесткие социальные лозунги в сочетании с манипулированием общественным мнением и сознанием приводят к длительным массовым протестным действиям.

В противостояние этим угрозам, на наш взгляд, следует формировать образ России будущего, где гражданское общество и властная вертикаль не находятся в состоянии перманентной войны, как их представляют
Западные идеологи, а взаимно дополняют друг друга, при этом институты гражданского общества служат гарантом баланса публичных и частных интересов.

Один яркий пример нового образа у нас есть - это «Бессмертный полк». Причем этот образ можно и нужно экспортировать, поскольку он является нашим новым и очень сильным оружием в гибридной войне. Нужны и другие образы, которые будут создавать представление о России как гаранте мировой безопасности. Представляется одним из таких образов также должно стать волонтерское движение, получившее свое официальное закрепление в ст. 114 новой редакции Конституции Российской Федерации. Значимость волонтерского движения, как одного из основных институтов гражданского общества, особенно в период пандемии коронавируса COVID-19 трудно переоценить. Волонтерская деятельность - один из действенных способов решения социально значимых задач государства. Деятельность волонтерских движений как ответ на пандемию коронавируса стала наиболее значима не только в России, но и во всем мире.

Сегодня на Западе одним из основных трендов является воспитание и выращивание так называемых «служебных людей». Суть здесь заключается в том, что они хорошо знают свою узкую специализацию и способны беспрекословно выполнять задачи, поставленные в ее рамках, при этом за границами этого коридора они ничем не интересуются. По сути, они нацелены на рост личного потребления и получение удовольствия. Именно такие методы нам навязывают наши зарубежные оппоненты, стремясь к деградации и атомизации нашего общества.

Манипулировать узконаправленным сознанием гораздо проще, дешевле и эффективнее. Поэтому главная защита от угрозы консциентальной угрозы - это образование. В связи с чем в интересах безопасности России главная задача должна быть прямо противоположной западной: воспитывать всесторонне развитых людей, которые не замыкаются в своей узкой специализированной нише, а рассматривают все вопросы, интересуются ими и активно участвуют в жизни общества.

Резюмируя вышеизложенное следует отметить, что руководство страны предпринимает все возможности для превенции рассмотренных угроз национальной безопасности.

Положения Стратегии национальной безопасности Российской Федерации утверждённой Указом Президента Российской Федерации от 2 июля 2021 г. № 400 идут в контексте поправок к Конституции Российской Федерации 2020 г., направленных на развитие демо- 
кратических начал российской государственности. При этом в третьем разделе Стратегии — «Национальные интересы Российской Федерации и стратегические национальные приоритеты» прежде всего прописаны положения о том, что «с учетом долгосрочных тенденций развития ситуации в Российской Федерации и в мире ее национальными интересами на современном этапе прежде всего является сбережение народа России, развитие человеческого потенциала, повышение качества жизни и благосостояния граждан.
Помимо защиты конституционного строя, суверенитета, независимости, государственной и территориальной целостности Российской Федерации, укрепление обороны страны также прописаны положения по поддержанию гражданского мира и согласия в стране, укрепление законности, искоренение коррупции, защита граждан и всех форм собственности от противоправных посягательств, развитие механизмов взаимодействия государства и гражданского общества» [9].

1. Конституция Российской Федерации

\section{ЛИТЕРАТУРА}

2. Указ Президента Российской Федерации от 21 июля 2020 г. № 474 «0 национальных целях развития Российской Федерации на период до 2030 года» http://publication.pravo.gov.ru/Document/View/0001202007210012

3. Постановление Правительства Российской Федерации от 20 октября 2020 г. № 1646 «0 мерах по обеспечению эффективности мероприятий по использованию информационно коммуникационных технологий в деятельности федеральных органов исполнительной власти» http://publication.pravo.gov. ru/Document/View/0001202010140027

4. Поручение Президента РФ от 5 августа 2021 г. «Перечень поручений по итогам заседания Совета по стратегическому развитию и национальным проектам» http://www.kremlin.ru/acts/assignments/orders/66331

5. Распоряжение Правительства РФ от 22 октября 2021 г. № 2998-р «0б утверждении стратегического направления в области цифровой трансформации государственного управления» http://publication.pravo.gov.ru/Document/View/0001202110260034

6. Распоряжение Правительства РФ от 6 ноября 2021 г. № 3144-р «06 утверждении стратегическое направление в области цифровой трансформации социальной сферы» http://government.ru/news/43660/

7. Материалы конференции по искусственному интеллекту Artificial Intelligence Journey (Al Journey 2020) на тему «Искусственный интеллект — главная технология XXI века». http://prezident.org/tekst/stenogramma-vystuplenija-putina-na-konferencii-po-iskusstvennomu-intellektu-12-11-2021.html

8. Дзлиев М.И. Когнитивное оружие - реальна ли угроза для национальной безопасности России?// Стратегические приоритеты. 2019. № 1 (21).С.77$86 \mathrm{http}: / /$ elibrary.ru/item.asp?id=39164453.

9. Указ Президента Российской Федерации от 2 июля 2021 г. № 400 «06 утверждении Стратегии национальной безопасности Российской Федерации http://prezident.org/articles/ukaz-prezidenta-rf-400-ot-2-iyulja-2021-goda-03-07-2021.html.

(с) Воронов Алексей Михайлович ( alex_voronoff@mail.ru ).

Журнал «Современная наука: актуальные проблемы теории и практики» 